\title{
Internal Quality Assurance System for the Higher Education: Experience of Ukraine and Poland
}

\author{
Mariusz Mazurkiewicz
}

$\mathrm{PhD}$, Associate Professor, Wroclaw University of Science and Technology, Poland

\section{Olga Liuta}

$\mathrm{PhD}$, Associate Professor, Sumy State University, Ukraine

\section{Konstantin Kyrychenko}

Head, International Affairs Office, Sumy State University, Ukraine

\begin{abstract}
The research paper investigates the state of the internal system of quality assurance for higher education and identifies the main approaches for its enhancement under the process of integration of Ukraine into the global educational area. The authors conducted a thorough analysis of the existing national and foreign approaches to the definition of "quality of education". It has been determined that at different stages of the historical development of the society the requirements for education and its quality have changed, along with the content of the latter category. At a modern stage, content "quality of education" is comprehensive and contains the characteristics of all components of learning, the conditions and results of the educational process.

A research on a practical nature of constructing and implementing the internal quality assurance system by the higher educational institutions of Ukraine has been carried out and the main shortcomings inherent in this process at the present stage has been determined on the basis of the survey conducted within the implementation of the international grant project "Quality Assurance System in Ukraine: Development on the Base of ENQA Standards and Guidelines" of the EU Erasmus + Programme. Among the main problems inherent in the internal quality assurance systems in Ukraine were determined the following: 1) ESG 2015, in particular regarding the internal quality assurance (namely, assurance, not just monitoring, evaluation, control), are still not completely comprehended and systematically not applied in national practice; 2) most of HEIs do not conduct student evaluation of time spent on studying the courses as well as analysis of their subjective evaluation of workload for learning; 3 ) insufficient provisions for internal systems of academic staff selection; 4) the low level of information transparency; limited information is publicly available to all internal and external stakeholders; 5) there is no common framework to which institutions can refer. This leads to strong differences in implementation of internal quality assurance procedures and thus to different results and outcomes.

The research paper describes the experience of Polish higher educational institutions in terms of the developing an internal quality assurance system for the higher education. The main task of the further work is to identify the main approaches for improving the internal quality assurance system at the Ukrainian higher education institutions based on application of the best European experience.
\end{abstract}

Keywords: higher education, educational activity, internal system of quality assurance, stakeholders, learners, standards, recommendations.

JEL Classification: I20, I23.

(C) The Authors, 2017. This article is published with open access at ARMG Publishing.

\section{Introduction}

The integration of Ukraine into the educational area simplifies the need for harmonization of Ukrainian higher education with the foreign educational systems. These tendencies lead to the emergence of the specific requirements for the national quality assurance system and the quality assurance processes of higher education within the universities, as the guarantee of quality of the education is one of the most important conditions for the recognition of a higher educational institution in the academic environment and in the labor market.

The issue of quality assurance in higher education has been relevant to the academic environment since the late $20^{\text {th }}$ century. Since the $1980 \mathrm{~s}$, the European governments have begun to abandon centralized regulation of the higher educational system and have switched to a policy of autonomy for the higher educational institutions, upon the condition of education quality assurance provided by the last. 
Therefore, in terms of nowadays conditions, the main responsibility for ensuring the quality of education belongs, first of all, to the higher educational institutions that create internal quality assurance systems based on the conformity of their educational programmes, material resources, scientific and methodological support, personnel potential and the management structure with the certain requirements of the country, society and personality.

\section{Literature review}

First of all, it is necessary to determine the definition "quality of education", examining the internal quality assurance system. At present, it is recognized at the world level, that the welfare, education, and human health are the main factors of the quality of the human`s life, and the quality of education is the main goal and the priority of the development of the society in the $21^{\text {st }}$ century. The notion "quality of education" is constantly evolving, depending on the level of the development of the society and in accordance with its needs. At the various stages of the historical development of the society the requirements for the education and its quality have changed, along with the content of the last category (Gos W., 2015). The analysis of the approaches to the quality of education in the domestic normative documents suggests that this category is considered in the context of both, a set of personality traits gained during the professional training of a specialist at the higher educational institution and the ability to satisfy certain requirements of the consumers or standards. Thus, in the Methodological Recommendations on the Development of Constituents of Branch Standards for Higher Education the "competence approach" is indicated as a set of qualities of a person with higher education, reflecting his/her professional competence, value orientation, social orientation and the ability to satisfy personal spiritual and material needs as well as the needs of the society (Gulo V., Levkivs'kyi K., Kotolovetc' L., 2013). The Law of Ukraine "On Higher Education" states that this is a level of knowledge, skills, abilities and other competences gained by a person that reflect his/her competence in accordance with the standards of higher education.The Law of Ukraine "On Education" defines the quality of education as the compliance of the results of the education process with the requirements established by law, the relevant standard of education and/or the agreement on the provision of the educational services.

The theme of the defining the quality of education is presented in the works of such domestic scientists as Andrushchenko V., Selezniova N., Kalashnikova S., Krasylnikova H., Kurbatov S., Lukhovii V., Rashkevych Yu., Finikov T., Sharov S.. The results of the study of the existing approaches to the interpretation of the category "quality of education" provide grounds for establishing that the views of individual scholars and academic schools on the "quality of education" differ significantly. Thus, considers the quality of the education as a social category that directly determines the intellectual potential of society. N. Selezniova, defining the quality of education as a social category, emphasizes the definition of the state and process of the education in the society, its compliance with the needs and expectations of the various social groups in the development and formation of the civil, domestic and professional competences of the individual (Selesneva N., 2002). At the same time, V. Zvonnikov and M. Chelyshkova believes that the "quality of education" in its broadest sense is an integral characteristic of the educational system, which reflects the real educational results achieved in accordance with the normative requirements, social and personal expectations of those, who study (Zvonnikov V., Chelyshkova M., 2009).

The examination of the definitions of foreign authors shows that there are four approaches to the content of quality: quality as purposeful, exceptional, transformative, and accountable. According to the approach "quality as purposeful" quality means that institutional products and services conform to a stated mission/vision or a set of specifications, requirements, or standards, including those defined by accrediting and/or regulatory bodies. The second approach "quality as exceptional" defines that institutional products and services achieve distinction and exclusivity through the fulfillment of high standards. Quality as transformative shows that Institutional products and services effect positive change in student learning (affective, cognitive, and psychomotor domains) and personal and professional potential. Speaking about quality as accountable, it is useful to pay attention to papers of American Society for Quality, where they wrote that institutions are accountable to stakeholders for the optimal use of resources and the delivery of accurate educational products and services with zero defect (Schindler L., Puls-Elvidge S., Welzant H., Crawford L., 2015).

As we see content "quality of education" is comprehensive and contains the characteristics of all components of learning, the conditions and results of the educational process. 


\section{Methods}

The methodological basis of the research consists of the cutting-edge concepts of the ensuring the quality of higher education, scientific works of domestic and foreign authors, devoted to the problems of assuring the quality of education. The following cutting-edge methods were used during the research: analysis, synthesis and scientific abstraction (specifying the category "internal quality assurance system"); comparative and statistical analyzes, method of logical generalization (studding the internal quality assurance systems in higher educational institutions of Ukraine).

The information factual basis of the study consists of: collected materials, worked out and summarized by the authors regarding the existing practice of building the internal quality assurance systems in Ukraine; official data of the Ministry of Education and Science of Ukraine; the legislative and normative acts; reporting data from the Institute of Educational Analysis; monographic studies and scientific publications on issues of the internal quality assurance in the higher education.

\section{Results}

The process of the constructing the internal quality assurance systems began in Ukraine after the implementation of the Law of Ukraine "On Higher Education", which states that the higher education institutions should have an internal quality assurance system. This system should include the following procedures and measures: definition of the principles and procedures for ensuring the quality of the higher education; monitoring and the periodic review of the educational programmes; annual assessment of the higher education applicants, scientific and pedagogical staff of a higher education institution, and the regular publication of the results of such assessments on the official website of the higher educational institution, also, on the announcement boards and in any other way; provision of the professional development of the scientific and pedagogical workers; ensuring the availability of the necessary resources for the organization of the educational process for each educational programme, including self-guided students work; ensuring the availability of the information systems for the effective management of the educational process; providing public disclosure of the information about the educational programmes, degrees of the higher education and the qualifications; providing an effective system for preventing and detecting the academic plagiarism in the scientific works of the teachers and students of the higher education institution (Standards and Guidelines for Quality Assurance in the European Higher Education Area (ESG), 2015).

It should be noted, the Law of Ukraine "On Higher Education" correlates significantly with the Standards and Guidelines for Quality Assurance in the European Higher Education Area (ESG 2015), which purpose is to improve the education in the European area, to help higher educational institutions to ensure and improve the quality of their activities and through the quality assure their rights on autonomy, to make the internal quality assurance more transparent and understandable (Standards and Guidelines for Quality Assurance in the European Higher Education Area (ESG), 2015).

The main goal of the ESG 2015 is to "contribute to the common understanding of quality assurance for learning and teaching in all EHEA countries and among all stakeholders" and the other aims are:

$>$ they set a common framework for quality assurance systems for learning and teaching at European, national and institutional level;

$>$ they enable the assurance and improvement of quality of higher education in the European higher education area;

$>$ they support mutual trust, thus facilitating recognition and mobility within and across national borders;

$>$ they provide information on quality assurance in the EHEA (ESG, 2015).

According to ESG 2015, to ensure the institutional quality assurance level the higher educational institutions conduct the activities the content of which is determined by the relevant component of the standard (Table 1) for the internal quality assurance.

Table 1. The content of the ESG 2015 and the content of the activities of a higher educational institution within ensuring its implementation (Vernydub R., 2015)

\begin{tabular}{|l|l|}
\hline \multicolumn{1}{|c|}{ Component of the standard } & \multicolumn{1}{c|}{ Contents of the activities to ensure the implementation of the standard } \\
\hline $\begin{array}{l}\text { The institution's policy and quality } \\
\text { assurance procedures }\end{array}$ & $\begin{array}{l}\text { To define a strategy, policy and the procedures for the constant improvement of the quality of } \\
\text { the education and to ensure the official status }\end{array}$ \\
\hline $\begin{array}{l}\text { Approval, control and a periodic } \\
\text { review of the programmes and } \\
\text { diplomas }\end{array}$ & $\begin{array}{l}\text { To develop and approve formally the mechanisms for periodic review, control and the } \\
\text { improvement of the academic programmes }\end{array}$ \\
\hline
\end{tabular}


Table 1 (cont.). The content of the ESG 2015 and the content of the activities of a higher educational institution within ensuring its implementation (Vernydub R., 2015)

\begin{tabular}{|l|l|}
\hline \multicolumn{1}{|c|}{ Component of the standard } & \multicolumn{1}{c|}{ Contents of the activities to ensure the implementation of the standard } \\
\hline Students assessment & $\begin{array}{l}\text { To develop, approve formally and to implement a knowledge assessment system that includes } \\
\text { a well-known criteria, rules and the moderation procedures }\end{array}$ \\
\hline $\begin{array}{l}\text { Ensuring the quality of the teaching } \\
\text { staff }\end{array}$ & $\begin{array}{l}\text { To identify the procedures and the criteria that would certify the relevant qualifications and the } \\
\text { high professional level of the teachers }\end{array}$ \\
\hline $\begin{array}{l}\text { Educational resources and students } \\
\text { support }\end{array}$ & $\begin{array}{l}\text { Sufficient supply with the educational and laboratory equipment and the teaching materials, } \\
\text { laboratory and study facilities that meet the programmatic requirements of teaching }\end{array}$ \\
\hline Informational systems & $\begin{array}{l}\text { Development, implementation and usage of the information systems for the collection, analysis } \\
\text { and usage of the objective information for the effective management of the academic } \\
\text { programmes }\end{array}$ \\
\hline Openness of the information & $\begin{array}{l}\text { Publication of the cutting-edge and the most objective information about the academic } \\
\text { programmes, the requirements for obtaining the academic degrees, the system of evaluation } \\
\text { and assessment }\end{array}$ \\
\hline
\end{tabular}

In recent years, a number of the sociological studies have been conducted in Ukraine to analyze in general the current state of the quality assurance system in the higher education and the internal quality assurance systems for higher education in particular.

Thus, according to the results of the sociological survey "Higher Education Reform" conducted in March, 2015 , more than $36 \%$ of respondents recognized the issue of improving the quality of the higher education in Ukraine as a priority issue, and more than $50 \%$ - as an important one. More than $25 \%$ of the respondents evaluate the quality of the higher education in Ukraine as a low, more than $50 \%$ - as an average, and only less than $25 \%$ - as a high one. The results of the conducted research testify to the current distrust of the society to this important institution, the decline of its prestige, and, also, it gives the grounds to assert the necessity of building a holistic quality assurance system at the domestic higher educational institutions (Gulo V., Levkivs'kyi K., Kotolovetc' L., 2013).

The analysis of design and implementation of internal quality assurance system in Ukrainian HEIs has been carried out in the context of implementation of international project QUAERE Quality Assurance System in Ukraine: Development on the Base of ENQA Standards and Guidelines" in the framework of ERASMUS+ program. In frameworks of this study the survey of Ukrainian HEIs on the state of the development of internal quality assurance system of educational activity and higher education has been conducted. The main idea of survey was to investigate how far or how close are Ukrainian HEIs from the ideas of quality assurance policy described in European Standards and Guidelines (Mariusz Mazurkiewicz, 2016).

The results of the study indicate a certain activities on building an internal quality assurance system for the higher educational institutions in Ukraine and the existence of the significant problems within the implementation of this process.

The ESG determines that educational programmes should be developed with the involvement of students and other stakeholders in the process, using the external expertise and the benchmarks. The data obtained on the basis of the results of the survey allow us to conclude that, before the formation of academic programmes in the higher educational institutions, mainly, the inner stakeholders are involved. The level of the students' and the external stakeholders' involvement is quite low (Table 2).

The respondents have been asked how HEI knows the student workload needed in order to reach the intended learning outcomes (or related educational achievements). In $45.8 \%$ of HEIs the teacher responsible for the module estimates the workload. This variant of estimation of student workload is not optimal, because project work group is responsible for the quality of study programme, and team decisions on the development of study programme and its separate components strengthen its integrity. The obtained results have showed that the level of student involvement in workload assessment is low (about 10\%): - all students indicate the workload they have for their courses only in $3.7 \%$ of HEIs; - a sample of students indicates the workload they have for their courses only in $6.5 \%$ of HEIs.

Table 2. Participation of different stakeholders in the design of curriculum

\begin{tabular}{|l|c|}
\hline \multicolumn{1}{|c|}{ Answers } & Share of respondents, \% \\
\hline Students & 28.0 \\
\hline Administrative staff members & 69.6 \\
\hline Academic staff members & 78.0 \\
\hline External stakeholders (employers/regional authorities/chamber of commerce etc.) & 32.7 \\
\hline Alumni & 9.8 \\
\hline Other & 5.1 \\
\hline
\end{tabular}


The important direction of questioning has been the studying of approaches of HEI to the assessment of study achievements of students. Respondents have been proposed to determine characteristics which correspond the student assessment procedures available in their HEIs (for example, conducting of examinations). HEI should control that assessment allows the presentation to the students the level in which the intended learning outcomes and other objectives of programmes have been achieved. It specifies by that fact that part of HEIs, in which it has been realized, makes only $51.9 \%$ (Table 3 ).

The role of a teacher is crucial in creating the high quality student experience and possibility of getting knowledge, competencies and skills. The survey results show that in general the HEIs are aware of their responsibility for the quality of staff and take a number of measures for its selection, training and, in some cases, dismissal.

The majority of the HEIs are oriented to external licensing and accreditation requirements in the selection of personnel. However, there are no specified requirements of HEI for competencies of permanent teaching staff when hiring them.

To ensure the appropriate level of higher education quality the HEIs provide a variety of learning resources to help students. The respondents have given the answer, how regularly the HEIs monitor, evaluate and/or improve the learning resources and make its offers.

Table 3. Characteristics of student assessment procedures

\begin{tabular}{|l|c|}
\hline \multicolumn{1}{|c|}{ Answers } & Share of respondents, $\%$ \\
\hline $\begin{array}{l}\text { Designed to measure the achievement of the intended learning outcomes and/or other programme } \\
\text { objectives }\end{array}$ & 51.9 \\
\hline Have clear and available for public criteria for giving grades & 83.2 \\
\hline Have clear, pre-defined examinations or other assessment methods in place & 82.2 \\
\hline Have clear regulations covering student absence, illness and other circumstances & 51.7 \\
\hline Ensure that assessments are conducted securely in accordance with the institution's stated procedures & 55.6 \\
\hline The administration checks that the assessment procedures are followed & 76.6 \\
\hline Other & 0.9 \\
\hline
\end{tabular}

Provided data indicate that the learning resources at the HEIs that participated in the survey range from physical resources such as libraries, laboratories and IT infrastructure (Internet access and e-mail students account system) to human support in the form of tutors, mentors, psychological support services and other consultants.

During the survey the respondents have determined whether there is a process/sub-process of monitoring the individual students' progression (i.e. the information relevant to the progression of particular students during their studies), continuing throughout the time necessary for students to obtain the degree.

Most of HEIs have such processes. However, $8.9 \%$ of HEIs must implement the processes and tools to collect and monitor the information on students' progression and take appropriate actions based on this information. (Figure 1).

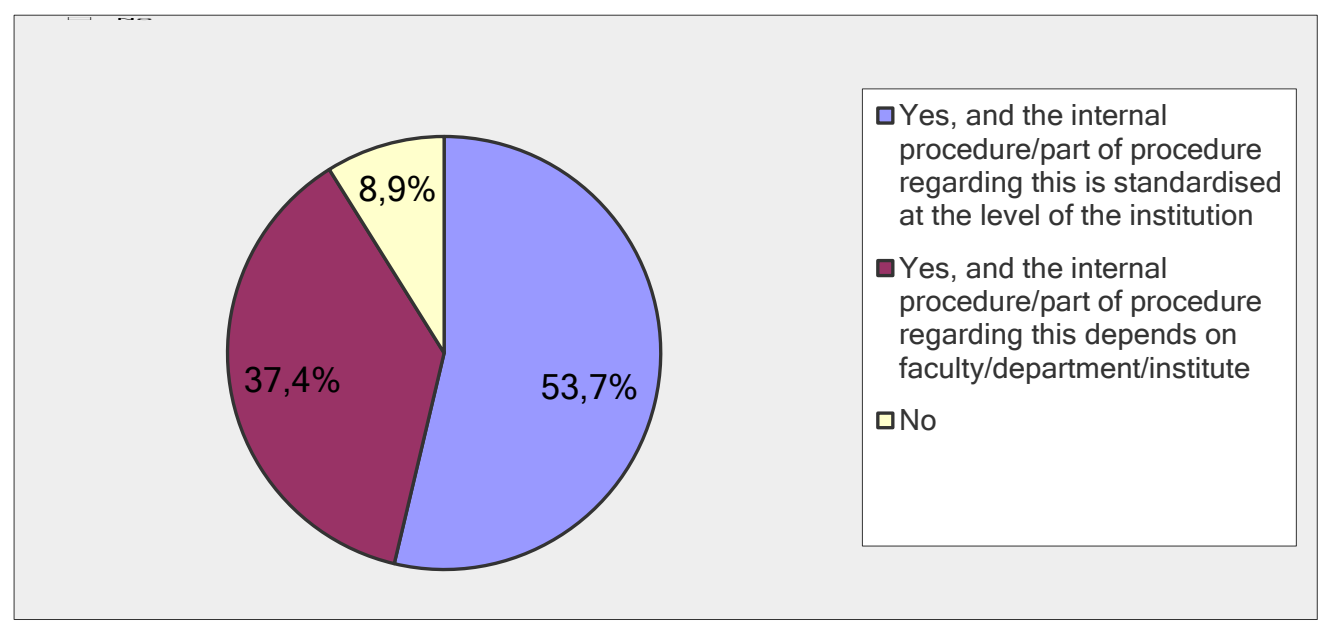

Figure 1. Existence of process for monitoring of individual students' progression through an entire degree cycle

While conducting the survey there has been studied the availability of processes/rules/mechanisms that support students during the learning process if they have massive difficulties to pass given courses. 
49.1\% of HEIs support students and on the request of students additional classes from given subjects can be organized. Herewith it is necessary to draw attention to the fact that $5.1 \%$ of HEIs that participated in the survey don't have processes/rules/mechanisms that support students during the learning process if they have massive difficulties to pass given course/subject/group of courses, etc.

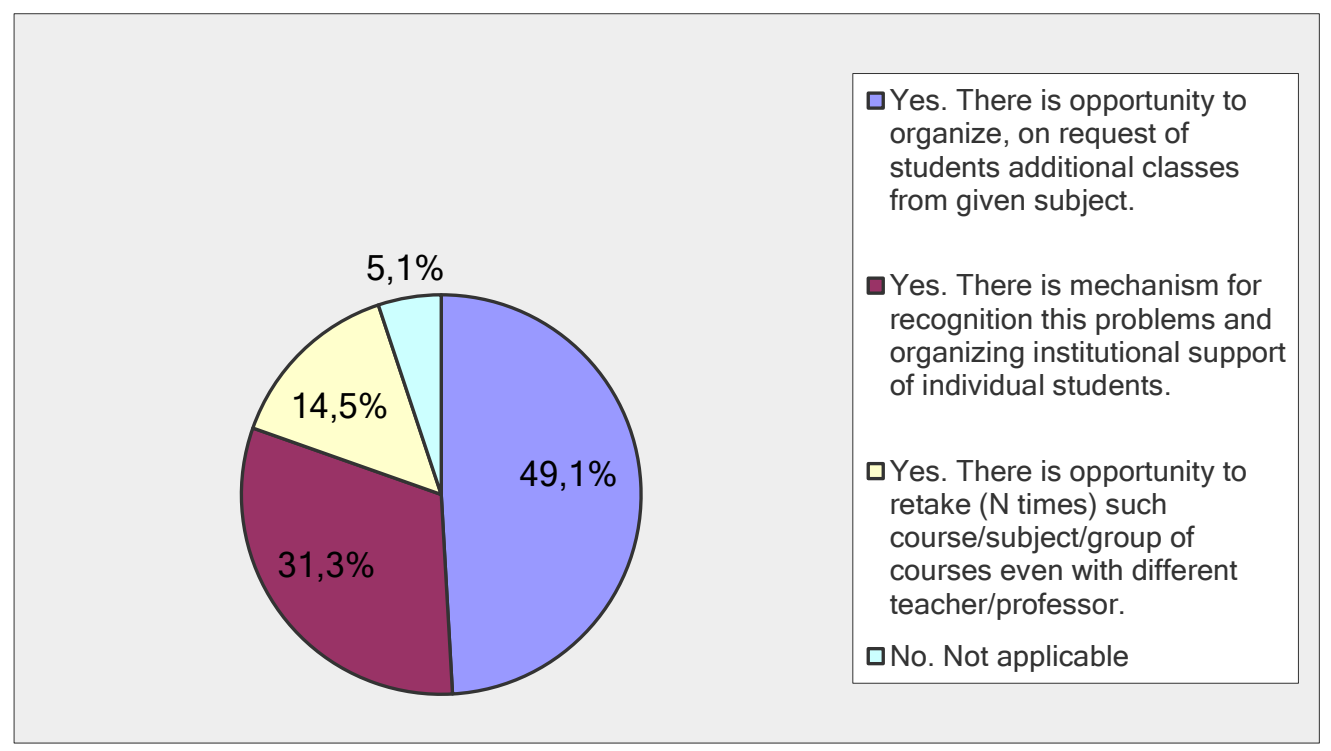

Figure 2. Existence of process for supporting students in learning process in case of difficulties to pass given course

For the effective management of their programmes and other activities the HEIs must provide the collection, analysis and use of relevant information. Therefore, the question of the organization of information systems is now especially important for the HEIs in Ukraine. The respondents have been proposed to answer the question "Does your institution have the information system (i.e. database) used for effective management of its activities in education/research/administration?". According to data obtained by questioning it may be concluded that national HEIs have significant problems concerning the formation and operation of information systems. Thus less than half of respondents $(42.1 \%)$ has said that the institution has a centralized information system that covers all key activities; $38.8 \%$ of respondents noted that the institution has a centralized, nonintegrated information system, and this leads to that fact that information about the different activities is not gathered in one data warehouse. The answer "Several information systems exist at the faculty/department level" has been chosen by $14.0 \%$ of HEIs. $5.1 \%$ of respondents indicated a lack of information system.

An important part of the internal quality assurance system is a publicity of information about educational activities of a HEI. According to ESG, information on the activities of institutions is useful both for future and current students, alumni and other stakeholders and public. Thus, institutions must provide information on their activities, including programmes that they offer and selection criteria for training; intended learning outcomes for these programmes; qualification granted by the programme; training procedures. In order to study particular aspects the respondents have been asked to define which components are the part of information about study programmes, that is publicly available. Distribution of answers to this question is presented in Table 4.

Table 4. Results of the survey on the information about study programmes of a HEI that is publicly available

\begin{tabular}{|l|c|}
\hline \multicolumn{1}{|c|}{ Answers } & Share of respondents, \% \\
\hline Number of students currently involved in the programme & 47.7 \\
\hline Number of academic staff involved in the programme & 51.4 \\
\hline $\begin{array}{l}\text { Teacher-student ratio in the respective faculty/department / } \\
\text { institute }\end{array}$ & 20.1 \\
\hline Information on the intended learning outcomes of the programme & 55.1 \\
\hline Information of qualifications granted by the programme & 79.4 \\
\hline $\begin{array}{l}\text { Information on the teaching, learning and assessment procedures } \\
\text { used within the programme }\end{array}$ & 66.8 \\
\hline $\begin{array}{l}\text { Information on the learning opportunities (e.g. traineeships, } \\
\text { exchange programmes, mobility possibilities, scholarships...) } \\
\text { available to the students of the programme }\end{array}$ & 53.3 \\
\hline Information on alumni career progress & 44.9 \\
\hline
\end{tabular}


Table 4 (cont.). Results of the survey on the information about study programmes of a HEI that is publicly available

\begin{tabular}{|l|c|}
\hline \multicolumn{1}{|c|}{ Answers } & Share of respondents, \% \\
\hline Information on graduates societies/clubs (contact data etc.) & 27.6 \\
\hline Profile of the current student population & 38.3 \\
\hline Specific information targeting international students & 19.2 \\
\hline $\begin{array}{l}\text { Detailed information on admission criteria published in } \\
\text { appropriate advance period }\end{array}$ & 79.9 \\
\hline $\begin{array}{l}\text { Detailed information (upon request) about reasons of negative } \\
\text { results (rejection of candidate) of admission procedure }\end{array}$ & 18.2 \\
\hline Accessibility and support offered to disabled students & 32.7 \\
\hline Other & 3.3 \\
\hline
\end{tabular}

The conducted study shows that most HEIs are characterized by fragmented disclosure of information by those components required by the Ministry of Education and Science of Ukraine. This makes it impossible to obtain clear, accurate, objective, timely and easily accessible information on the activities of the university, including study programmes and reduces the efficiency of the internal quality assurance system.

During the survey analysis, the following challenges have been identified:

1. ESG 2015, in particular regarding the internal quality assurance (namely, assurance, not just monitoring, evaluation, control), are still not completely comprehended and systematically not applied in national practice.

2. Most of HEIs do not conduct student evaluation of time spent on studying the courses as well as analysis of their subjective evaluation of workload for learning.

3. Insufficient provisions for internal systems of academic staff selection.

4. The low level of information transparency; limited information is publicly available to all internal and external stakeholders.

5. There is no common framework to which institutions can refer. This leads to strong differences in implementation of internal quality assurance procedures and thus to different results and outcomes.

In order to study the best European practices for the establishment of the internal quality assurance systems, it is reasonable to conduct a study of the Polish experience concerning the building of the internal quality assurance systems for the higher education.

The commitment to create internal quality assurance systems was formulated in Polish legislation for the first time in the year 2007. The government regulations in a very general way defined what internal quality assurance is, leaving the design and implementation of internal quality assurance systems to individual HEIs or their organizational units (Selesneva N., 2002).

Modern internal quality assurance systems in higher education institutions in Poland are characterized by the following features (Standards and Guidelines for Quality Assurance in the European Higher Education Area (ESG), 2015):

$>$ internal quality assurance systems constituted;

$>$ internal regulations adopted;

$>$ the formal, tailored HEI's systems structure implemented;

$>$ responsibilities for processes to ensure quality divided;

$>$ administrative units supporting the functioning internal quality assurance systems established;

$>$ participation of representatives of all categories of stakeholders in the structures of systems provided;

$>$ in most HEIs sets of evaluation, assurance and improvement procedures developed; - systems for collecting data on key areas of assessment and quality assurance built.

According to the results of survey of Polish HEI aimed to collect data on overall progress that HEIs had made in the implementation of their IQA systems the status of adaptation of the ESG 2015 by the Polish higher education institutions is rather high (Table 5). 
Table 5. Status of adaptation of the ESG 2015 by the Polish higher education institutions (Kwiatkowska Sujka I., Socha M., Polish Accreditation Committee, 2016)

\begin{tabular}{|c|c|}
\hline Standard of ESG 2015 & Implementation in Polish Universities \\
\hline $\begin{array}{l}\text { ESG 1.1. Policy for } \\
\text { quality assurance }\end{array}$ & $\begin{array}{l}\text { Over } 50 \% \text { of HEIs have a published policy for quality assurance and external stakeholders were involved } \\
\text { in both the development and implementation of the policy. In most cases quality strategic goals are } \\
\text { directly incorporated by HEIs into strategic plans and they do not develop separate documents for their } \\
\text { quality assurance policy. Cooperation with external stakeholders shows an increasing tendency for the } \\
\text { last few years and confirms the significant response of the HE sector to the labour market needs. It is } \\
\text { also reflected in legal requirements and assessment criteria of the PKA relating to the IQAs. }\end{array}$ \\
\hline $\begin{array}{l}\text { ESG 1.2. Design and } \\
\text { approval of } \\
\text { programmes }\end{array}$ & $\begin{array}{l}\text { The procedure for design and approval of programmes is not followed in all fields of study. While the } \\
\text { approval procedure does not generate a problem for respondents, the designing procedure is declared as } \\
\text { a weakness. Nevertheless, the majority of programmes are designed in line with institutional strategies, } \\
\text { mission statements and vision and refer to the National Qualification Framework. The involvement of } \\
\text { external stakeholders in the procedure of design and approval still require more attention. }\end{array}$ \\
\hline $\begin{array}{l}\text { ESG 1.3. Student- } \\
\text { centered learning, } \\
\text { teaching and assessment }\end{array}$ & $\begin{array}{l}\text { Students are systematically involved in IQA activity, and student-centered learning, teaching and } \\
\text { assessment is said to be well understood by HEIs. However, the actual implementation of this range of } \\
\text { issues in the revised ESG should be more fully addressed. Fairness and consistency achieved through } \\
\text { the procedure of student assessment was quite misunderstood by most HEIs and over } 70 \% \text { respondents } \\
\text { decided to skip the question. }\end{array}$ \\
\hline $\begin{array}{l}\text { ESG } 1.4 \text {. Student } \\
\text { admission, progression, } \\
\text { recognition and } \\
\text { certification }\end{array}$ & $\begin{array}{l}\text { HEIs apply consistent regulations concerning student admission, recognition and certification. At } \\
\text { present, the development of regulation on the recognition of non-formal and informal learning } \\
\text { constitutes a great challenge for the IQAs. Under the Law on Higher Education, the recognition of } \\
\text { nonformal and informal learning by HEIs will have been implemented by Senates till 30th June } 2015 \text {. }\end{array}$ \\
\hline ESG 1.5. Teaching staff & $\begin{array}{l}\text { As regards the legal requirements including obligatory assessments of teaching staff the survey results } \\
\text { confirmed that the performance of teaching staff is assessed on a regular basis. The remaining activities } \\
\text { which include professional development opportunities provided to teaching staff, incentives to } \\
\text { encourage the professional development of teaching staff, incentives to encourage the use of new } \\
\text { technologies in teaching, or mechanism for rewarding teaching achievements vary greatly among units } \\
\text { and fields of study. The main problem is linked to the regular monitoring of teaching staff satisfaction. }\end{array}$ \\
\hline $\begin{array}{l}\text { ESG 1.6. Learning } \\
\text { resources and student } \\
\text { support }\end{array}$ & $\begin{array}{l}\text { Similarly, the compliance with ESG 1.6. varies greatly among different fields of study and units. At } \\
\text { present, all of responding HEIs provide academic, financial and personal advice to students. Besides, } \\
\text { they have in place a mechanism for informing students about the support and services available. At the } \\
\text { same time there are still HEIs which declare that they do not have a mechanism for assessing the } \\
\text { adequacy and accessibility of learning resources or student support, or do not have in place procedures } \\
\text { to ensure that administrative staff are properly qualified to deliver support services. }\end{array}$ \\
\hline $\begin{array}{l}\text { ESG 1.7. Information } \\
\text { management }\end{array}$ & $\begin{array}{l}\text { The majority of HEIs have a formal mechanism for analyzing and using data collecting for quality } \\
\text { assurance enhancement purposes e.g. key performance indicators, profile of the student population, } \\
\text { student progression, success and drop-out rates, students' satisfaction with programmes, etc. It shows a } \\
\text { fairly good observance of standard requirements by HEIs. }\end{array}$ \\
\hline $\begin{array}{l}\text { ESG 1.8. Public } \\
\text { information }\end{array}$ & $\begin{array}{l}\text { HEIs provide full information about the programmes they offer, including admission criteria, full } \\
\text { curricula, syllabuses etc. However, some of them declare that some legal requirements (data protection } \\
\text { law) might hinder public information activities. }\end{array}$ \\
\hline $\begin{array}{l}\text { ESG 1.9. On-going } \\
\text { monitoring and periodic } \\
\text { reviews of programmes }\end{array}$ & $\begin{array}{l}\text { External stakeholders are still not fully involved in the on-going monitoring and periodic reviews of } \\
\text { programmes. This is still a new development in Polish HE, which has recently been regulated by the } \\
\text { Law on Higher Education. Higher education institutions shall co-operate with the socio-economic } \\
\text { environment, in particular by conducting research and development for business entities on the basis of } \\
\text { organizationally and financially independent economic structures, including the establishment of a } \\
\text { special purpose vehicle (SPV), referred to in Article 86a of the Law on Higher Education, as well as } \\
\text { through the involvement of employers' representatives in the development of study programmes and } \\
\text { teaching processes. Nevertheless, PKA has noticed some progress in this respect. }\end{array}$ \\
\hline
\end{tabular}

From formal point of view ESG 2015 are fully implemented in polish HEIs, however the current solutions applied within the field quality assurance are built without a reference to a strategic, long-term vision of development of higher education system as a whole (Brdulak, J., 2016). It means that in general the internal and external quality assurance systems work, but there are still a list of unsolved problems (Godłów-Legiędź, J., 2016;5). First of all it concerns the following directions:

$>$ ensuring the active participation of students, as internal stakeholders, in the creation and monitoring of educational activity through surveys on the quality of teaching, the quality of educational components and the quality of educational resources;

$>$ wider involvement of external stakeholders (social partners) in the internal quality assurance of higher education, especially in the creation and monitoring of educational programs;

$>$ implementation of procedures and mechanisms for the recognition level of achievement of learning outcomes; 
analysis and monitoring of the satisfaction of the teaching staff policy correlated with salary policy inside HEIs.

\section{Conclusions and discussion}

Based on the research results, it could be concluded that process of implementation of the European standards in higher education systems for Poland and Ukraine is running now. The presented characteristics of internal quality assurance systems of higher education in Poland and Ukraine show that the Polish system is closer to the standards of ESG 2015. But it is necessary to mention that the activity at the level of higher education institutions in Ukraine is gradually increasing in compliance with the requirements of the European standards and recommendations. Further expanding of involvement of internal and external stakeholders is significant important for Polish higher educational institutes as well as Ukrainians ones. More over Polish and Ukrainian HEIs should pay special attention to the development of quality culture in which all internal stakeholders assume responsibility for quality and engage in quality assurance at all levels of the institution. Shaping the culture of quality should be done not through the compulsion of Ministry of Education or other bodies responsible for evaluation of internal quality assurance system, but by understanding the values and importance of standards by academics society, by discussion and dissemination of the best experience.

\section{References}

1. Andrushchenko, V., Bojchenko, M., Gorbunova, L., Nadolnij, I. (2012). Philosophical and methodological principles for improving the quality of higher education in Ukraine: European dimension. Pedagogichna dumka, $220 \mathrm{p}$.

2. Brdulak, J. (2016). Quality assessment of HEIs in Poland: Problems and recommendations (in Polish) Ocena jakości kształcenia w Polsce - problemy i rekomendacje, Nauka i Szkolnictwo Wyższe, 48(2): 8194. DOI: 10.14746/nisw.2016.2.4.

3. Brockerhoff, Lisa, Huisman, Jeroen, Laufer, Melissa. Quality in higher education: literature review (2015). Resource document. https://www.onderwijsraad.n1/upload/documents/publicaties/volledig/Quality-inHigher-Education-A-literature-review-1.7.pdf

4. Development of the Quality Assurance System for Higher Education in Ukraine: Information and Analytical Review. General edition by Kalashnikova S., Lukhovii V. (2015). Resource document. https://ihed.org.ua/images/biblioteka/Rozvitok_sisitemi_zabesp_yakosti_VO_UA_2015.pdf

5. Godłów-Legiędź, J. (2016) Polish Higher Education in Transition and Quality of Education (in Polish). Studia Prawno-ekonomiczne, t. XCVIII, 2016. PL ISSN 0081-6841 s. 197-219.

6. Gos W. (2015). The Quality of Education at Universities - the Voice in Discussion (in Polish). FOLIA Pomeranae Universitatis Technologiae Stetinensis, Folia Pomer. Univ. Technol. Stetin., Oeconomica 2015, 319(79)2, 69-76.

7. Gulo, V., Levkivs'kyi, K., Kotolovetc', L. (2013). Methodical recommendations on the development of components of standards of higher education (competence approach). Resource document. http://sumdu.edu.ua/images/stories/gen_info/structure/methodical/Methodical_references.pdf.

8. Improving quality, enhancing creativity: Change processes in European higher education institutions final report of the quality assurance for the higher education change agenda (QAHECA) PROJECT. - EUA Publications (2009). Resource document. http://www.eua. be/eua-work-andpolicy-area/qualityassurance/qaheca. aspx.

9. Krasyl nykova, G. (2015). Monitoring of the quality of professional training of engineers of the garment industry at a higher educational establishment: theoretical and methodical principles. Khmelnyczkyj National University, $543 \mathrm{p}$.

10.Kwiatkowska, Sujka I., Socha, M., Polish Accreditation Committee. (2016). Enhancing internal quality assurance systems. Country report: Poland. Resource document. http://files.clickweb.home.pl/homepl42655/file/r2countryreport-poland.pdf.

11.Law of Ukraine "On Education". (2017). Resource document. http://zakon3.rada.gov.ua/laws/show/2145-19. 12.Law of Ukraine "On Higher Education". (2014). Resource document. http:// www.vnz.org.ua/zakonodavstvo/ 111-zakon-ukrayiny-pro-vyschu-osvitu.

13.Mazurkiewicz, Mariusz. (2016). Quality Assurance in Higher Education Institutions in Ukraine through the prism of European Guidelines and Standards ESG 2015. Resource document. https://depot.ceon.pl/bitstream/handle/123456789/11264/publication_1p.pdf?sequence=1\&isA llowed=y.

14.Parri, J. (2006). Quality in Higher Education. Management. 2, 107-111. 
15.Reform of higher education in Ukraine: the implementation of the profile law in 2014-2016. Resource document. http://parlament.org.ua/wp-content/uploads/2016/12/HE-shadow-report-final.pdf.

16.Schindler, L., Puls-Elvidge, S., Welzant, H., Crawford, L. (2015). Definitions of Quality in Higher Education: A Synthesis of the Literature. Resource document. https://www.hlrcjournal.com/index.php/HLRC/article/view/244/217.

17.Selesneva, N. (2002). Quality of higher education as a systemic research object: lecture-report. Resource document. http://misis.ru/Portals/0/IKVO/Selezneva/link_A_selezneva.pdf.

18.Standards and Guidelines for Quality Assurance in the European Higher Education Area (ESG). (2015). Resource document. http://www.enqa.eu/wp-content/uploads/2015/11/ESG_2015.pdf.

19.Sursock, A. (2015). Trends 2015: Learning and Teaching in European Universities, European University Association, Brussels, Belgium.

20.Vernydub, R. (2015). Providing European standards of quality of higher education. Resource document. http://www.ird.npu.edu.ua/files/vernudyb 12.pdf.

21.Zvonnikov, V., Chelyshkova, M. (2009). Quality control of certification at certification (competency approach). Universitetskaya kniga, 272 p. 